Relations industrielles

Industrial Relations

\title{
Le syndicalisme chrétien - Études économiques et sociales - VI - Confédération des Syndicats chrétiens de Belgique, Bruxelles, 1951, 220 pp.
}

\section{Fernand Jolicoeur}

Volume 7, numéro 1-2, décembre 1951, mars 1952

URI : https://id.erudit.org/iderudit/1023126ar

DOI : https://doi.org/10.7202/1023126ar

Aller au sommaire du numéro

\section{Éditeur(s)}

Département des relations industrielles de l’Université Laval

ISSN

0034-379X (imprimé)

1703-8138 (numérique)

Découvrir la revue

Citer ce compte rendu

Jolicoeur, F. (1951). Compte rendu de [Le syndicalisme chrétien - Études économiques et sociales - VI - Confédération des Syndicats chrétiens de Belgique, Bruxelles, 1951, 220 pp.] Relations industrielles / Industrial Relations, 7(1-2), 134-134. https://doi.org/10.7202/1023126ar

Tous droits réservés (C Département des relations industrielles de l’Université Laval, 1952
Ce document est protégé par la loi sur le droit d'auteur. L'utilisation des services d'Érudit (y compris la reproduction) est assujettie à sa politique d'utilisation que vous pouvez consulter en ligne.

https://apropos.erudit.org/fr/usagers/politique-dutilisation/ 


\section{BOOKS and REVIEWS}

\section{PRIVATE ENTERPRISE}

Two recent publications of the "Association des Patrons et Industriels Chrétiens de Belgique" (APIC) on private enterprise, subject of its last annual convention:

Rev. L. Brouwers, s.J., La doctrine sociale de l'Eglise et l'entreprise, a booklet of 12 pages.

The author, after a short introduction, considers in succession, in regard to the papal teachings, capital in the enterprise, work in the enterprise, and management in the enterprise. For a more complete review, please refer in the French section to the article written by Mr. Gerard Dion.

Georges Henry, Comment maintenir le caractère privé de l'entreprise, tout en réalisant l'intégration des travailleurs, a booklet of 16 pages, Association des Patrons et Ingénieurs catholiques, 17, rue du Gouvernement Provisoire, Bruxelles.

This study begins with a vibrant appeal to employers to be realistic, to "discover the principal need of the times and consecrate themselves to it", and to "translate in facts and particularly in all socio-economic structures, the new necessities". The author then analyzes the situation of the workers in the enterprise to justify the necessity of their integration. He discusses profit-sharing and employee stock ownership, and proposes in the last part, the ways of realizing this integration of the workers in the enterprise.

For a more complete review by Mr. Gerard Dion, please refer to the French section.

\section{TRADE-UNIONISM}

Le syndicalisme chrétien - Etudes économiques et sociales - VI - Confédération des Syndicats chrétiens de Belgique, Bruxelles, 1951, 220 pp.

In our country, the Catholic syndicates have long been considered as organizations of social appeasement, which counterbalanced the labour movement of which the force and exacting tendencies are feared. Then, little by little, the attitude of the Canadian and Catholic Confederation of Labour, in recent years, has caused disturbance and today it is difficult to know what to think of the recent statement of principles of this labour movement that proposes most advanced economic and social reforms, and that refers constantly to the social doctrine of the Church.

Is the Christian unionism therefore taking part also in the claims of the popular masses against the established order? What is its reason for being within the structure of the labour movement? This is a problem which dates nearly fifty years, but which takes on today an increasing interest on account of the development of trade-unionism and the present complexity of the social problem.

For this reason, the study which has just been published by the Confederation of Christian Synlicates of Belgium (Confédération des Syndicats chrétiens de Belgique) on Christian Trade-unionism, its nature and its mission must draw the attention of all those who are more or less interested in the labour movement. It is a very elaborate study which covers both the ideological and practical aspects of the problem.

A more complete review of this book appears in the French section of this issue. 